\title{
The Financial Crisis at the Kitchen Table: Trends in Household Debt and Credit
}

\author{
Meta Brown, Andrew Haughwout, Donghoon Lee, \\ and Wilbert van der Klaauw
}

\begin{abstract}
Since the onset of the financial crisis, households have reduced their outstanding debt by about $\$ 1.3$ trillion. While part of this reduction stemmed from a historic increase in consumer defaults and lender charge-offs, particularly on mortgage debt, other factors were also at play. An analysis of the New York Fed's Consumer Credit Panel - a rich new data set on individual credit accounts - reveals that households actively reduced their obligations during this period by paying down their current debts and reducing new borrowing. These household choices, along with banks'stricter lending standards, helped drive this deleveraging process.
\end{abstract}

$\mathrm{S}$ ince the start of the financial crisis, the liabilities side of household balance sheets has been the subject of urgent interest among policymakers and the media. Aggregate trends documented in the Federal Reserve System's Flow of Funds Accounts demonstrate a steep run-up in consumer debt from 1999 to 2008, followed by a pronounced decline through at least third-quarter 2012. According to most views, the crisis began in the residential mortgage market, as an increasingly large number of borrowers, especially in the nonprime segment, became delinquent on their mortgage payments. The increase in delinquencies and the enormous rise in residential mortgage foreclosures soon developed into a full-blown financial crisis and led to one of the sharpest market contractions in U.S. history. While many trends in the financial system played a role in these developments, household behavior was clearly a fundamental contributor.

Since the financial crisis eased and economic growth resumed in the second half of 2009, many analysts have pointed to consumer behavior as a crucial determinant of the vigor and sustainability of the economic recovery. ${ }^{1}$ In this article, we use a rich new data set on individual credit accounts to investigate the behavior underlying these aggregate trends. Our data set—-the Federal Reserve Bank of New York (FRBNY) Consumer Credit Panel—is an ongoing panel of quarterly data on individual and household debt (see box). It is created from a large sample of U.S. consumer credit reports provided to the New York Fed by Equifax, one of three national credit reporting agencies. The data allow for reliable high-frequency measurement of trends in aggregate debt. Unlike the Flow

\footnotetext{
${ }^{1}$ See, for example, Federal Reserve Governor Elizabeth A. Duke's speech at Ohio Banker's Day, http://www.federalreserve.gov/newsevents/speech/duke20100630a.htm, and Federal Reserve Governor Sarah Bloom Raskin's speech at the New America Foundation, http://www.federalreserve.gov/newsevents/speech/raskin20110629a.htm.
} 


\section{The New York Fed's Consumer Credit Panel}

The FRBNY Consumer Credit Panel represents a 5 percent random sample of U.S. individuals with credit files as well as all of their household members. ${ }^{a}$ In all, the data set includes anonymous credit files on more than 15 percent of the population, or approximately 37 million individuals. We use information from the credit reports for those individuals for each quarter during the last thirteen years, with current data through September 2012.

The sampling exploits randomness in the last two digits of individuals' Social Security numbers. ${ }^{\mathbf{b}}$ The procedure ensures that the Panel is dynamically updated in each quarter to reflect new entrants into credit markets. In addition, Equifax, the data provider, matches the primary individual's mailing address to all records in the data in order to capture information about other members of the primary individual's household. These individuals are also added to the sample. This procedure enables us to track individuals and households consistently over time, thus allowing us to study richer dynamics of consumer debt and related policy issues at both the individual and household level.

Our credit report data includes residential location at the census block level and the individual's month and year of birth. The data also contain detailed information on each individual mortgage loan, including

- origination date,

- original balance,

- current balance,

- current (scheduled) payment,

- current status (that is, current, thirty-days delinquent, and so on).
While the mortgage information in the data set is very detailed and, we believe, complementary to loan-level information available from sources like LoanPerformance and LPS (McDash), it differs in important ways from these sources. In particular, the mortgage information does not indicate the seniority of individual mortgage loans. However, because the FRBNY Consumer Credit Panel data are collected at the borrower level, they offer a different perspective on mortgage debt than is available in standard loan-level data sets.

In addition to information on debts secured by residential real estate, the data set includes somewhat more aggregate data on individuals' and households' other loans, such as credit cards, auto loans, and student loans. Here, the data include the following:

- total number of accounts of each type (for example, the total number of bank-issued credit cards),

- credit limit on each type of account (for example, the combined credit limit on all credit cards), ${ }^{\mathrm{C}}$

- total balance on each type of account in each status (for example, the total student loan balance that is current, thirty-days delinquent, and so on).

More general information on the credit report includes the following:

- indicators for whether the individual has a foreclosure or bankruptcy within the last twenty-four months, and ever, on the report;

- indicators for whether the individual has any accounts in collection and the amount of collection;

- a consumer score that is analogous to the well-known FICO score.

\footnotetext{
a See Avery et al. (2003) for a detailed discussion of the contents, sources, and quality of credit report data.

b See Lee and van der Klaauw (2010) for further details about the sample design and content of the FRBNY Consumer Credit Panel.

${ }^{c}$ This field is known as the "high credit" amount in the credit report data. It refers to either the credit limit (for credit cards, home equity lines of credit, and other revolving debt) or the highest balance (for mortgages, auto loans, and other installment debt). There are instances in which credit limits on revolving accounts are unreported, in which case the high credit variable reflects the historical high credit level for the account. Avery et al. (2003) and Hunt (2002) point out that the reporting of credit limits in credit reports has improved considerably in recent years.
}

of Funds Accounts and related industry-sourced aggregate data, the Panel data enable us to observe debt accumulation, repayment, and delinquency at the individual consumer level.

We begin by using the Consumer Credit Panel to produce new measures of aggregate debt trends since 1999. Our evidence, like evidence obtained from the Flow of Funds Accounts, shows that the level of household debt, after a sustained period of increase, began to decline in 2008; moreover, aggregate delinquencies peaked at the end of $2009 .{ }^{2}$ Furthermore, while debt continues

\footnotetext{
${ }^{2}$ While we compare the Consumer Credit Panel to the Flow of Funds here, there are important conceptual differences between the two, including the fact that the Flow of Funds measures include nonprofit organizations that are absent from the Consumer Credit Panel measures. See Lee and van der Klaauw (2010).
}

to decline, total delinquencies have shown signs of stabilization in the Consumer Credit Panel in recent quarters. Next, we apply the Panel's consumer-level data to address the claim that the decline in aggregate debt derived entirely from "charge-offs"defaults written off borrowers' credit records by lenders—and not from a decline in consumers' reliance on debt or an increase in their debt repayment. We decompose consumer debt changes into three components: charge-offs, housing transaction-derived changes, and more standard refinancing and repayment. We find that between 2008 and 2010, households switched from borrowing to repaying, resulting in a nearly $\$ 500$ billion reduction in annual consumer cash flows from debt between the precrisis period and 2010. 
Chart 1

Total Debt Balance and Its Composition

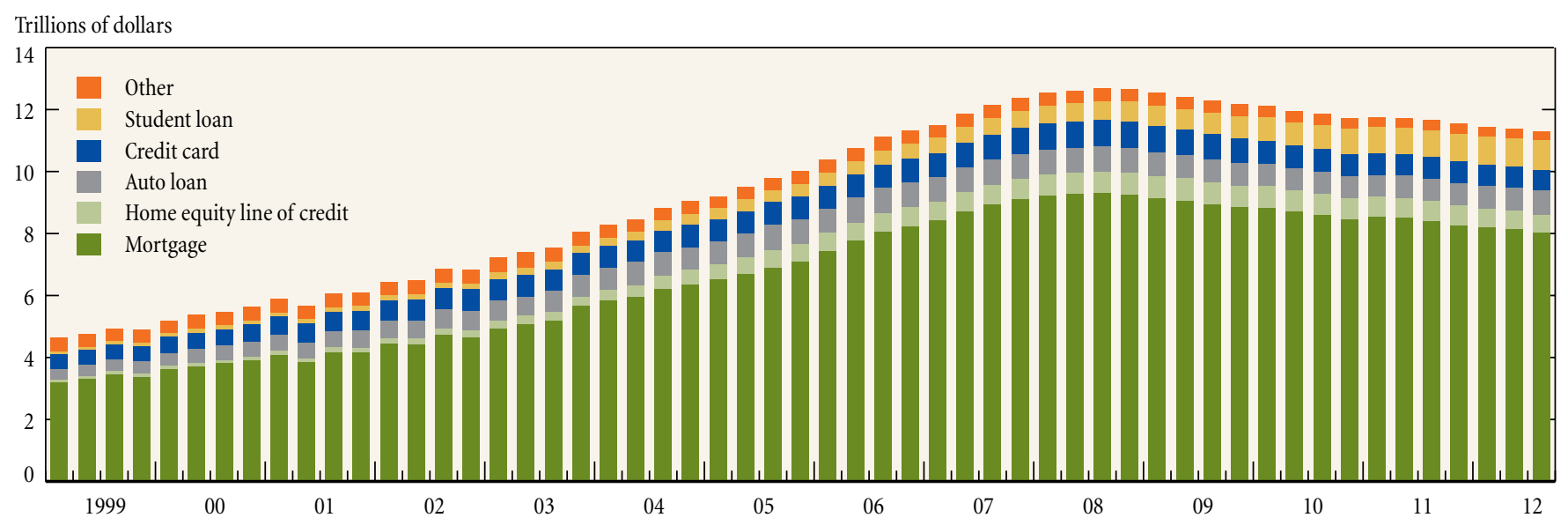

Source: Federal Reserve Bank of New York Consumer Credit Panel/Equifax.

Note: Student loan data prior to 2003 reflect some delays in the reporting of student loans by servicers to credit bureaus. This could lead to some undercounting of student loan totals in specific periods and impact other student loan-specific measurements. However, variability in student loan balances prior to 2003 does not materially affect the aggregate debt time series because the variability is small relative to the total balances. Other components of household debt are unaffected.

\section{Consumer Debt during the Precrisis Period}

From first-quarter 1999 (when our data begin) through thirdquarter 2008, we observe substantial increases in consumer indebtedness. On March 31, 1999, consumers owed about $\$ 4.6$ trillion to creditors. During the subsequent nine years, consumer indebtedness rose more than 170 percent, reaching $\$ 12.7$ trillion at the end of third-quarter $2008 .^{3}$ The driving force behind these changes was debt secured by residential real estate, which accounts for the great majority - more than 70 percent in all periods — of household liabilities. Amounts owed on installment mortgages and home equity lines of credit (HELOCs) tripled over this periodfrom $\$ 3.3$ trillion to $\$ 10$ trillion-accounting for $\$ 6.7$ trillion of the total $\$ 8$ trillion increase in consumer liabilities. Nonetheless, other forms of consumer debt also rose sharply, nearly doubling from $\$ 1.4$ trillion to $\$ 2.7$ trillion. Many factors were responsible for these increases, including rising populations, incomes, stock and house prices, falling interest rates, and the democratization of credit. Indeed, while consumer indebtedness-the liabilities side of the household balance sheet - was rising sharply, the Flow of Funds Accounts indicate that assets owned by the household sector were growing as well, leaving consumers' net wealth (the difference between the value of assets owned and liabilities owed) to grow steadily over the period.

Like the Consumer Credit Panel, the Flow of Funds Accounts show an increase in consumer debt from 1999 through mid-2008. Housing's share of overall debt is roughly 70 to 80 percent during the period in both series, and the relative contributions of housing

\footnotetext{
${ }^{3}$ By comparison, GDP rose about 58 percent over the period, from $\$ 9.1$ trillion to $\$ 14.4$ trillion.
}

and nonhousing debt to the consumer debt climb are similar in the Panel and Flow of Funds.

Delinquency rates remained stable from 1999 through 2006 in the Consumer Credit Panel, with roughly 4 percent of total outstanding debt thirty or more days past due (delinquent) and 2 percent of total debt ninety or more days past due (severely delinquent). However, delinquency rose quickly during 2007 , reaching 6.7 percent by the end of the year and 8.5 percent by the peak of consumer debt in third-quarter 2008. Severe delinquency climbed to 3.6 percent by the end of 2007 and 5.1 percent by third-quarter 2008. Hence, the data reveal both a precrisis period of credit expansion associated with very steady consumer debt performance and emerging evidence of repayment difficulties as early as 2007.

\section{Consumer Debt since the Financial Crisis}

Since the end of third-quarter 2008, U.S. consumers have reduced their indebtedness by $\$ 1.4$ trillion, resulting in a decrease in the aggregate consumer debt balance from $\$ 12.7$ trillion at its peak in third-quarter 2008 to $\$ 11.3$ trillion at the end of third-quarter 2012. Chart 1 shows the total debt observed on credit reports for the entire life of the Panel, in the aggregate and broken down by loan type. Total household debt has decreased roughly 11 percent since its peak. Mortgage-related debt now accounts for 76 percent of total debt, with the remainder comprising credit cards, auto loans, student loans, and other consumer debt. ${ }^{4}$

\footnotetext{
${ }^{4}$ Since the earliest iterations of the Consumer Credit Panel, a major change has occurred in the measurement of student loan indebtedness. For more on the changes we have made to our definitions of student loans, see page 2
} 
Chart 2

\section{Total Debt Balance by Delinquency Status}

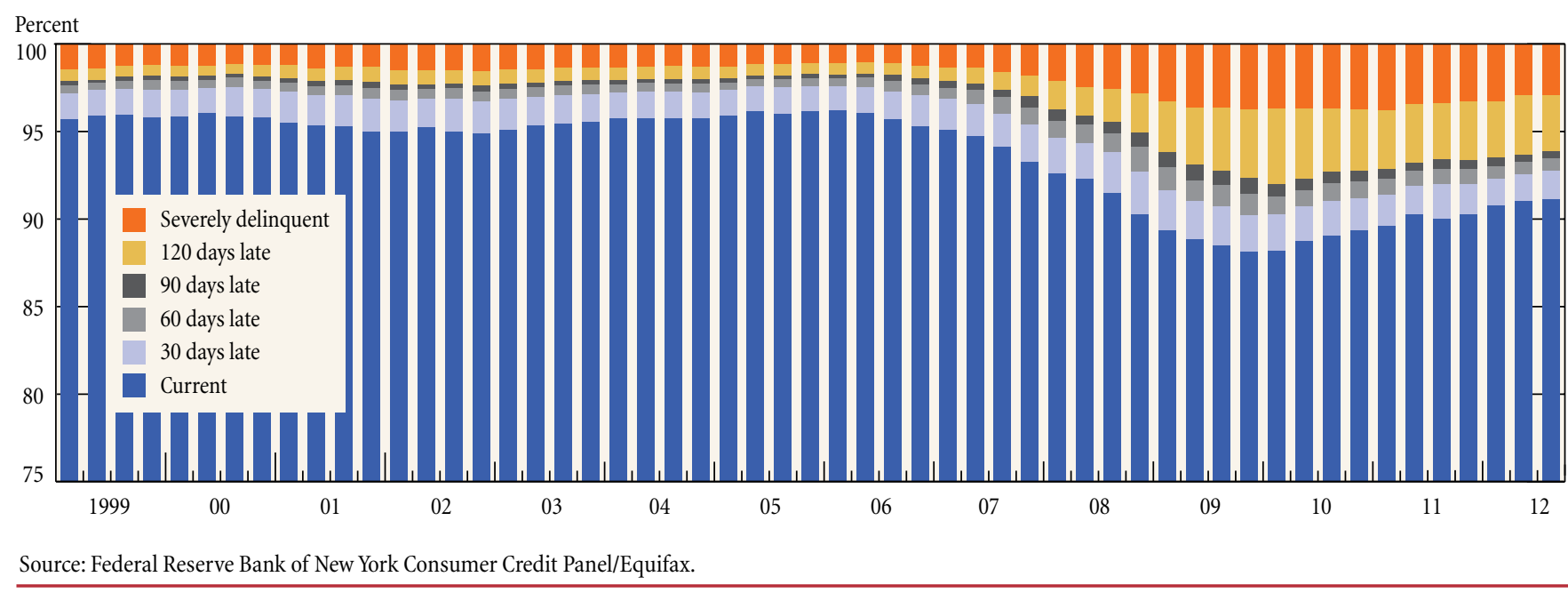

Like the Consumer Credit Panel, the Flow of Funds Accounts indicate a substantial decline in outstanding household debt from its 2008 peak to the present. The magnitude of the decline in the Flow of Funds is lower, however, at slightly more than $\$ 960$ billion. Both series indicate steep declines in debt (more than 3 percent) in 2009: in the Flow of Funds, declines are moderate ( 0.2 percent to 1.6 percent per year) starting in 2010 , while the Panel indicates continued declines of 1.5 percent to 3.7 percent annually through third-quarter 2012. Lee and van der Klaauw (2010) discuss some additional differences in the measurements.

Delinquency in the Consumer Credit Panel continued to climb following the debt peak in third-quarter 2008, reaching its maximum level to date in fourth-quarter 2009 (see Chart 2). At that point, delinquency had grown from its previously stable 4-to5 percent of outstanding debt to 11.9 percent. Severe delinquency peaked in first-quarter 2010 at 8.7 percent of outstanding debt, despite having never reached 3 percent for the entire 1999-2006 period. Put differently, delinquency and severe delinquency rates roughly tripled and quadrupled, respectively, over a period of three-and-a-half years. It is interesting to see that the deterioration of household debt started as early as the end of 2006 and accelerated from that point through fourth-quarter 2009.

Both measures of delinquency declined decisively from fourth-quarter 2009 to third-quarter 2012, the most recent available quarter of data. For third-quarter 2012, delinquency stands at 8.9 percent of outstanding debt and severe delinquency at 6.6 percent. These figures represent a decline of roughly 25 percent

\section{Footnote 4 continued}

of the 2011:Q3 Quarterly Report on Household Debt and Credit, available at http://www.newyorkfed.org/research/national_economy/householdcredit/ DistrictReport_Q32012.pdf.

\section{Chart 3 \\ Flow into Delinquency by Loan Type: Annual Rate for the Preceding Four Quarters}

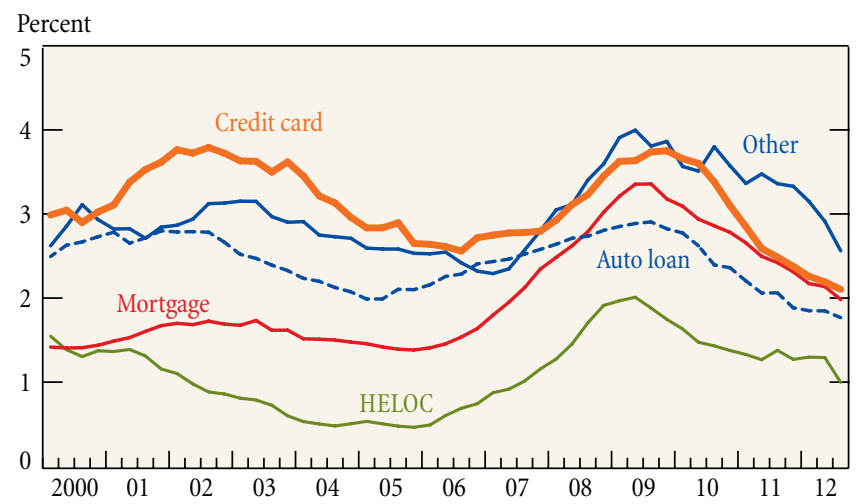

Source: Federal Reserve Bank of New York Consumer Credit Panel/Equifax.

Note: HELOC is home equity line of credit.

in each case. The downward trend in delinquency rates was broken only once, with a one-quarter uptick in early delinquencies in third-quarter 2011.

The "flow into delinquency" is a measure of debt balances that were previously current but became newly delinquent in each quarter. Chart 3 shows that debt performance deteriorated across all debt types, but the deterioration of installment mortgage debt- excluding HELOCs - preceded that of other categories. Between fourth-quarter 2005 and fourth-quarter 2008, new installment mortgage delinquencies tripled, from $\$ 98$ billion to more than $\$ 310$ billion. After that, the deterioration of mortgage 
Chart 4

\section{Number of New Foreclosures and Bankruptcies}

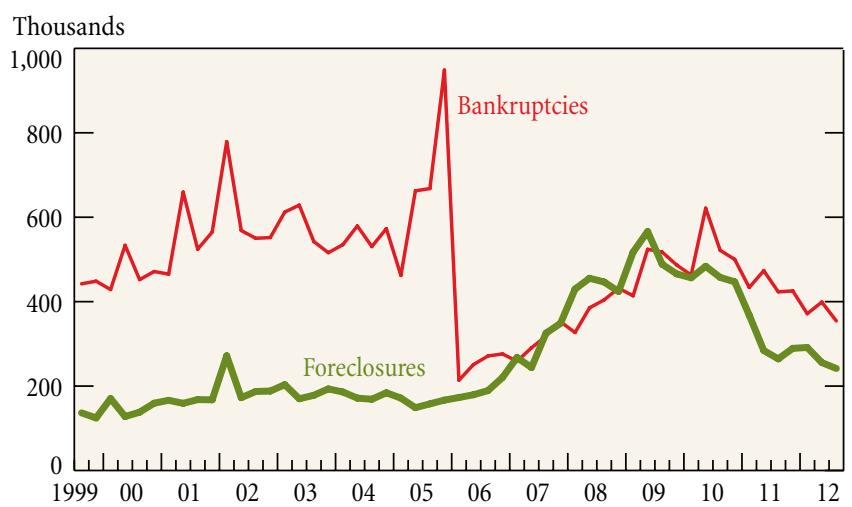

Source: Federal Reserve Bank of New York Consumer Credit Panel/Equifax.

debt slowed steadily. New mortgage delinquencies reached a recent low of $\$ 140$ billion in third-quarter 2012. ${ }^{5}$

Recent improvements in the performance of mortgage and other household debt are naturally reflected in a decrease in foreclosures and personal bankruptcies. ${ }^{6}$ Chart 4 shows the quarterly number of new foreclosures and bankruptcies nationwide, with approximately 2 million people experiencing a new foreclosure and approximately 2 million experiencing a new bankruptcy in 2009. Bankruptcies and especially foreclosures declined substantially between second-quarter 2010 and third-quarter 2012. The second-quarter 2010 to third-quarter 2012 decline in bankruptcies, when annualized, implies a decrease of 1,068,480 annual filings. The second-quarter 2010 to third-quarter 2012 decline in foreclosures, when annualized, implies a decrease of 968,320 individual foreclosure experiences. ${ }^{7}$

\footnotetext{
${ }^{5}$ Delinquencies and defaults in mortgage loans basically drive the patterns in total debt in Chart 2, given that mortgage-related debt accounts for 70-to80 percent of the aggregate debt balance. Although mortgages are responsible for much of the magnitude of consumer debt, the prevalence of mortgage debt among U.S. households is either similar to or substantially less than the prevalence of credit card debt, depending on the measure. Bucks et al. (2009) find in the 2007 Survey of Consumer Finances that 48.7 percent of households hold home-secured debts; we observe 42.3 percent of September 2007 Panel households with homesecured debts. Bucks et al. show 46.1 percent of households reporting credit card balances; we find that 76.1 percent of September 2007 Panel households have positive credit card balances on their credit reports. (This discrepancy between lender and borrower debt reporting is the subject of Zinman [2009] and Brown et al. [2011].)

${ }^{6}$ The spike in the personal bankruptcy rate in 2005 is due to the (much anticipated) change in bankruptcy laws that made filing for bankruptcy more difficult after that year. See, for example, Morgan et al. (2008).

${ }^{7}$ It is important to reiterate that this measure of new foreclosures is at the individual level. It is the number of individuals with a foreclosure newly added to their credit reports, as opposed to the number of mortgages or houses with a foreclosure notice, a more commonly reported figure. New foreclosures are counted at the individual level by utilizing an indicator to determine whether the person has experienced a foreclosure start during the past twenty-four months. Thus an individual who sequentially defaulted on several mortgages within a
}

\section{Nonmortgage Debt Changes other than Charge-Offs}

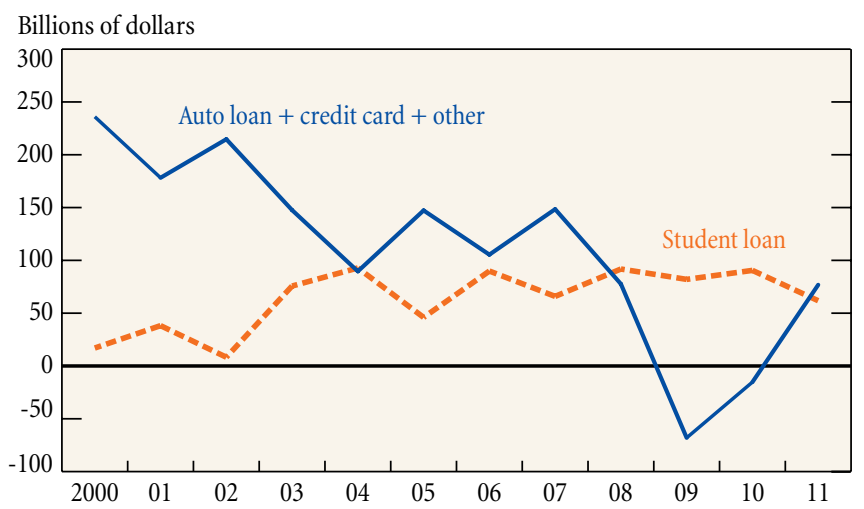

Source: Federal Reserve Bank of New York Consumer Credit Panel/Equifax.

Note: Student loan data prior to 2003 reflect some delays in the reporting of student loans by servicers to credit bureaus. This could lead to some undercounting of student loan totals in specific periods and impact other student loan-specific measurements. However, variability in student loan balances prior to 2003 does not materially affect the aggregate debt time series because the variability is small relative to the total balances. Other components of household debt are unaffected.

\section{How Are Consumers Reducing Their Debts?}

The unusual decline in consumers' use of credit that we have observed in the last four years raises the question of its sources. At least three major mechanisms could be at work:

1. declining consumer use of, and demand for, credit;

2. declining lender supply of credit; and

3. an increasing amount of nonperforming debt written off by lenders as a result of the sudden increase in default rates.

Since a large increase in charge-offs occurred at the same time as the decline in debt, the third mechanism is a good place to begin. If charge-offs explain the entire reduction in debt outstanding, then there is little need to look further in order to understand the roles played by the other two mechanisms. So we now turn to the question: Is the reduction in consumer indebtedness mainly attributable to defaults, or are consumers actively reducing their debts-either voluntarily or because credit has become very difficult to obtain?

For nonmortgage debt, answering this question is relatively straightforward. Chart 5 shows the annual change in nonmortgage debt after stripping out charge-offs. We break nonmortgage debt into two components - student loans and all other loans (including credit cards and auto loans). Until 2009, consumers were increasing both components of their

Footnote 7 continued

twenty-four-month period would appear as a new foreclosure only once: when the first mortgage went into foreclosure. Further, in the case of a joint mortgage account, two separate individuals could experience the same foreclosure. 
Chart 6

\section{Decomposition of Changes in Mortgage Balances}

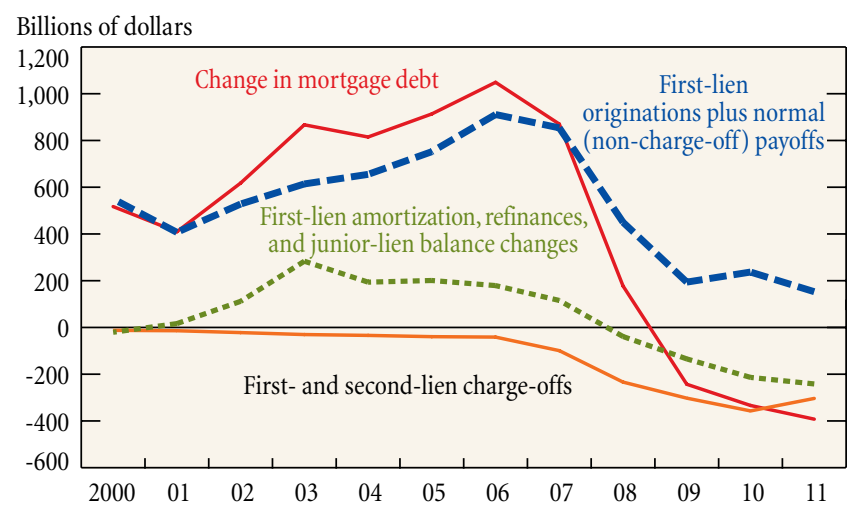

Source: Federal Reserve Bank of New York Consumer Credit Panel/Equifax.

nonmortgage debt obligations each year. In 2009 and 2010, net nonmortgage borrowing — other than student loans-became negative ( $\$ 68$ billion and $\$ 15$ billion, respectively), but student debt continued to grow. Since consumers had been borrowing an average of more than $\$ 200$ billion per year between 2000 and 2007 using nonmortgage debt, this indeed looks like a change in consumers' reliance on credit other than student debt.

Mortgages are more complicated because after a charge-off and foreclosure, there is typically a house that can be resold, albeit often at a discounted price. For example, a borrower defaults on her $\$ 100,000$ mortgage and the lender repossesses her house. The lender then resells the house to a new buyer, who pays $\$ 80,000$ for the property, making a 20 percent down payment and financing the remaining $\$ 64,000$ with a thirty-year mortgage. The amount charged off on the original borrower's credit report in this case is $\$ 100,000$, but the net change of mortgage indebtedness from this series of events is only $-\$ 36,000(=\$ 64,000$ minus $\$ 100,000)$. We do not have property-level data on housing debt, and therefore cannot infer the amount of a charged-off mortgage balance recovered by the bank through resale of the asset or the resulting contribution to aggregate mortgage debt by the new owner. This data shortcoming prevents us from allocating percentages of the mortgage debt decline to: 1) a net charge-off and 2) changes in active borrowing and repayment. We can, however, investigate active borrowing and repayment behavior among mortgage holders over the period of aggregate debt decline.

We focus on this type of behavior by dividing the change in mortgage balances (Chart 6 , solid red line) into three components. ${ }^{8}$

1. Changes in mortgage debt related to housing transactions (Chart 6, dashed blue line) include payoffs of mortgages associated with the "normal" — that is, outside of

\footnotetext{
${ }^{8}$ Our approach to decomposing the change in mortgage debt is related to the method adopted by Greenspan and Kennedy (2008).
}

foreclosure - sale of a house from one owner to another and the opening of new first mortgages for the purpose of buying a home, whether it is for sale by the previous owner or a lender. As expected, this series has fallen sharply as the value of housing transactions has declined. In this calculation, we exclude the reduction in debt attributable to charge-offs.

2. For convenience, we also show the negative contribution of charge-offs to mortgage balances (Chart 6, solid orange line). We see here clear evidence of the foreclosure crisis, as charge-offs on mortgage debt total around $\$ 1.3$ trillion from 2007 through 2011.

3. Our final series (Chart 6, dashed green line), combines cash-out refinances of first liens, changes in junior-lien balances including HELOCs, and regular amortizations of first-lien balances.

While first-lien amortization reduces balances at a fairly steady pace, the other components have declined sharply since 2007. We interpret this component of balance changes as indicative of consumer responses to economic and financial conditions. While consumers were, on average, extracting equity and increasing their mortgage debt until 2007, they have started to pay down debt since then. Between 2000 and 2007, consumers increased their real estate indebtedness by an average of $\$ 135$ billion per year. In 2008, this series turned negative and reached $-\$ 241$ billion in 2011.

Taken together, the mortgage and nonmortgage series reported here indicate a major change in consumer behavior other than delinquency and default. While all kinds of borrowing contributed an annual average of about $\$ 350$ billion to consumers' cash flows between 2000 and 2007, by 2010 consumers reduced their cash flows by $\$ 138$ billion to reduce this debt. This represents a nearly $\$ 500$ billion change in annual cash flow from debt in just three years.

So did consumers reduce their use of debt? Yes. Holding aside defaults, from 2007 through 2011, consumers reduced their debt at a pace not seen over the last ten years. A remaining issue is whether this reduced reliance on debt is a result of borrowers being forced to pay down debt as credit standards tightened, or a more voluntary change in saving behavior.

\section{Is the Debt Reduction Voluntary?}

A number of measures available in the FRBNY Consumer Credit Panel provide some insight into whether consumers' debt paydown is voluntary, or the product of tightened credit standards. First, the Panel includes information on the stock of open credit accounts. Chart 7 shows a substantial decrease in the number of open accounts, especially credit card accounts, since the second-quarter 2008 peak. At the peak, the data reflected nearly 500 million credit card accounts in total. By third-quarter 2010, 
Chart 7

\section{Total Number of Accounts by Loan Type}

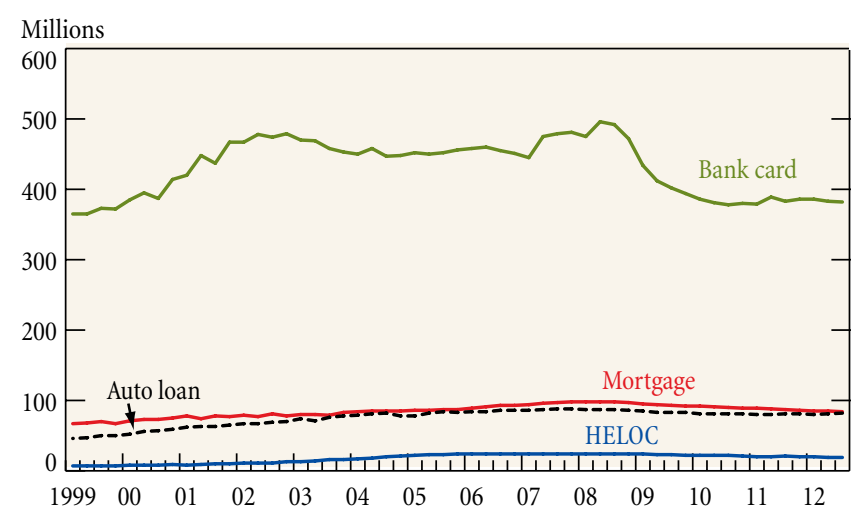

Source: Federal Reserve Bank of New York Consumer Credit Panel/Equifax.

Note: HELOC is home equity line of credit.

that figure had dropped nearly a quarter, to 378 million accounts, a level that has been relatively stable over the last two years. This represents a striking change over a short period in U.S. consumers' use of revolving credit.

This net loss of 120 million credit card accounts does not, in itself, tell us whether consumers are choosing to reduce the number of credit cards they hold - and presumably their available credit —or whether lenders are restricting new credit and terminating old borrowing relationships in the aftermath of the crisis, or both. The Consumer Credit Panel series on account openings and closings and on credit report inquiries sheds some light on the question.

The blue line in Chart 8 shows the total number of installment and revolving accounts opened within twelve months for each quarter of the available years of data. The rate of new account openings is high and flat through the middle of the decade, but then begins a decline in early 2008 that continues through third-quarter 2010. By then, quarterly account openings had fallen nearly 40 percent, from a peak of roughly 250 million in each quarter from third-quarter 2005 to third-quarter 2007, to 158 million in third-quarter 2010. Since then, the number of account openings has increased modestly, to 177 million, but remains well below its peak sustained levels.

Of course, new account openings may slow either because consumers seek fewer new accounts or because lenders deny more applications. Data on credit report inquiries help us make a distinction here. In general, the type of credit report inquiry registered by our inquiry variable is triggered by consumer applications for credit. Therefore, holding the credit quality of applicants constant, if the number of inquiries were to remain stable while the number of new account openings fell significantly, it would be reasonably safe to infer that creditors' standards had risen, and lenders were responsible for the decline in new accounts.

\section{Total Number of New and Closed Accounts and Inquiries}

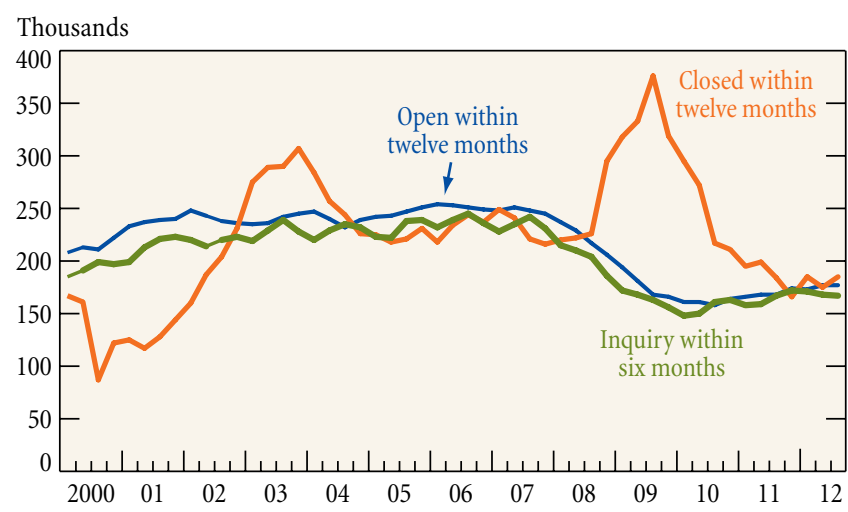

Source: Federal Reserve Bank of New York Consumer Credit Panel/Equifax.

If quality-adjusted inquiries track new accounts, however, then consumers would appear to have helped generate at least some of the decline in new accounts by decreasing their applications for credit. ${ }^{9}$ It is possible, of course, that consumers are not applying for credit because they believe that lending standards have tightened. In addition, the decline in inquiries is likely to reflect a reduction in credit card offers to consumers. Our data by themselves thus cannot absolutely distinguish whether supply or demand has declined. Aggregate inquiries data do, however, offer a partial picture of consumer actions relating to account openings.

The credit report inquiries series in Chart 8 (green line) tracks the new account series quite closely. As the twelve-month rate of new account openings falls by more than a third from its 2005-07 plateau of around 250 million to a low of 158 million in third-quarter 2010, the rate of inquiries quite similarly drops from a plateau of around 240 million inquiries per six-month period from 2005-07 to a second-quarter 2010 low of 150 million inquiries, before bouncing back slightly and stabilizing at around 165 million inquiries - very near the twelve-month account openings level during the last two years of data. The available evidence suggests that fewer applications for credit from borrowers contributed to the decline in new account openings.

The drop in new account openings is only half of the picture for credit account transitions. The orange line in Chart 8 shows the number of credit account closings in the past twelve months for each quarter in the Panel. Account closings have risen since 1999, although not steadily. From third-quarter 2008 to thirdquarter 2009, closings underwent a sudden, steep increase from 226 million to a peak of 376 million. They have since moderated to

\footnotetext{
${ }^{9}$ One caveat is that not all credit inquiries go to all credit bureaus, and our data come from a single bureau. If our coverage of the reporting market is relatively stable over time, then our conclusions should be reliable. However, if there are large shifts in lenders' preferred credit reporting firms over the Panel, then these could appear as changes in inquiry rates in our data and could generate spurious credit report inquiry trends unrelated to consumers' actual application choices.
} 


\section{Chart 9}

\section{Credits Limits and Balances for Credit Cards and HELOC Accounts}

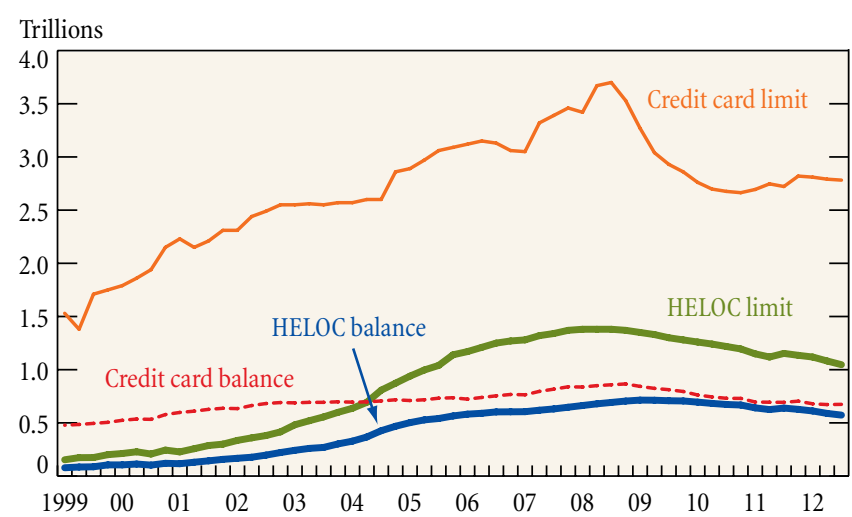

Source: Federal Reserve Bank of New York Consumer Credit Panel/Equifax.

Note: HELOC is home equity line of credit.

185 million, slightly below their 2004-08 levels. So at a time when new account openings were quite depressed, due at least in part to a drop in consumer applications for credit, accounts were also being closed in record numbers. As with account openings, we cannot infer from the account closing rate whether borrowers or lenders were primarily responsible for closing existing accounts. However some lenders - including Citibank, Bank of America, Advanta, and Chase Bank-reportedly closed large numbers of accounts in 2009, particularly troubled and inactive accounts. ${ }^{10}$ These results are consistent with recent survey evidence indicating that 13 percent of consumers had a credit card account closed by their bank during 2009 (Chakrabarti et al. 2011).

Chart 9 documents a steep, nine-quarter decrease in borrowing limits on credit card accounts from third-quarter 2008 to thirdquarter 2010, followed by a recent stabilization and an ongoing (if less pronounced) borrowing limit decrease for home equity revolving accounts. For credit cards, total credit limits decreased by 28 percent over the nine quarters, pushing up the utilization rate (balance divided by credit limit) by 4 percentage points, despite a decline in credit card balances during the period. Credit card utilization rates have fallen since 2010, as consumers have paid down balances faster than limits have declined. At the same time, the relatively modest HELOC limit decrease, in the face of nearly flat HELOC balances, led to a 5 percentage point increase in utilization that has persisted through third-quarter 2012. Consumers seldom request reductions in their credit limit. ${ }^{11}$ Further, in quarterly Federal Reserve Senior Loan Officer Opinion Surveys (Board of

\footnotetext{
${ }^{10}$ See two American Banker articles by Kate Fitzgerald: “Bill Due for '09 Account Closings," March 8, 2010, and "Issuers Found to Cut Inactive Accounts," September 14, 2010.

${ }^{11}$ Some portion of the decline in aggregate credit limits derives from the closing of accounts.
}

Governors of the Federal Reserve System 2008-10), large fractions of loan officers reported lowering credit limits for existing consumer accounts from April 2008 through early 2010. The data thus suggest that both borrowers and lenders have acted to curtail consumers' existing credit in the face of growing delinquency rates and broader financial market uncertainty.

\section{Conclusion}

The FRBNY Consumer Credit Panel provides a unique look into household borrowing and debt payment behavior. Overall, the Panel suggests that while tightened lending standards have played a major role in the declining liabilities of the household sector, consumer-initiated reductions in debt have contributed as well. This conclusion raises the further question of why households chose to reduce their debt, especially during a period in which many saw their incomes stagnate or drop. Here our data are less informative, but we can combine them with other data sets to form some explanations. Two merit special attention.

The first is that the decline in consumer debt is temporally correlated with the very rapid rise in unemployment rates in the second half of 2008. Rising unemployment affects consumer debt decisions in two potentially offsetting ways. First, households may choose to build their precautionary savings (or increase their available credit) to insure their cash flows against a job loss. This action would tend to reduce debt balances outstanding. Second, households that do experience a job loss may use their credit accounts to smooth their consumption, leading to more borrowing. ${ }^{12}$ Undoubtedly, the data in Charts 5 and 6 reflect the net effects of both types of household behavior. The overall decrease in debt would seem to suggest that the precautionary motive dominates. However, concurrent changes in asset values and other factors confound such conclusions. As the economic outlook improves, reductions in unemployment risk should temper the demand for precautionary saving by households and lower borrowing to smooth consumption during unemployment spells, with an uncertain net effect.

A second possible source of decline in consumer debt comes from the other (asset) side of household balance sheets. Here we focus on mortgage debt, the major form of collateralized household debt. An important consequence of the initial increase and subsequent drop in average housing prices for households is the dramatic fall in home equity. According to the Federal Reserve's Flow of Funds Accounts, total equity of homeowners rose with the increase in home prices. However, it did so at a much lower rate, with homeowners' equity share in their homes actually staying relatively constant until the end of 2006. On average, for each 1 percent rise in home prices, homeowners increased their mortgage debt by 1 percent (through higher balances on first mortgages, cash-out refinances, second mortgages, and home

\footnotetext{
12 A more detailed discussion of the potential influences of recent events on household saving can be found in Chakrabarti et al. (2011).
} 
equity lines of credit), so that their equity share in their homes actually remained constant. When home prices began to fall in 2007, owners' equity in household real estate began to fall rapidly, from almost $\$ 13.5$ trillion in first-quarter 2006 to a little less than $\$ 5.3$ trillion in first-quarter 2009 - a decline in total home equity of more than 60 percent. At the end of 2009, owners' equity was estimated at $\$ 6.3$ trillion, still more than 50 percent below its 2006 peak. Given that the recent decline in housing prices is unprecedented since the Great Depression, we have little evidence on the effect of such large declines in housing wealth on the demand for debt. However, if a large decline in net worth can in fact be expected to increase the marginal value of net saving, then the drop in owner's equity may have induced significant net saving via mortgage debt reduction, among other methods.

In light of (modest) recent improvements in credit availability, an important question is how much further consumers' voluntary actions will lower aggregate debt before they begin to spend again. This question is important for the economic outlook. While household debt pay-down has helped improve household balance sheets, it has also likely contributed to slow consumption growth since the beginning of the recession. Thus, the trajectory for consumer indebtedness has important implications for consumption and economic growth going forward. We will continue to monitor these important trends in our data, and make key information available on our website. ${ }^{13}$

\section{References}

Avery, Robert B., Paul S. Calem, and Glenn B. Canner. 2003. "An Overview of Consumer Data and Credit Reporting." Federal Reserve Bulletin, February: 47-73.

Board of Governors of the Federal Reserve System. 2008-10. "Senior Loan Officer Opinion Survey on Bank Lending Practices." April. Available at http://www.federalreserve.gov/boarddocs/snloansurvey.
Brown, Meta, Andrew Haughwout, Donghoon Lee, and Wilbert van der Klaauw. 2011. "Do We Know What We Owe? A Comparison of Lender- and BorrowerReported Debt.” Federal Reserve Bank of New York Staff Reports, no. 523, October.

Bucks, Brian K., Arthur B. Kennickell, Traci L. Mach, and Kevin B. Moore. 2009. "Changes in U.S. Family Finances from 2004 to 2007: Evidence from the Survey of Consumer Finances." Federal Reserve Bulletin, February: 1-55.

Chakrabarti, Rajashri, Donghoon Lee, Wilbert van der Klaauw, and Basit Zafar. 2011. "Household Debt and Saving during the 2007 Recession." Federal Reserve Bank of New York Staff Reports, no. 482, January.

Federal Reserve Bank of New York. 2011. "Quarterly Report on Household Debt and Credit." May. Available at http://www.newyorkfed.org/research/national _economy/householdcredit/DistrictReport_Q12011.pdf.

Federal Reserve Statistical Release, G.19, Consumer Credit. June 2010. Available at http://www.federalreserve.gov/releases/g19/Current/g19.pdf.

Greenspan, Alan, and James Kennedy. 2008. "Sources and Uses of Equity Extracted from Homes." Oxford Review of Economic Policy 24, no.1 (spring): 120-44.

Hunt, Robert M. 2002."The Development and Regulation of Consumer Credit Reporting in America." Federal Reserve Bank of Philadelphia Working Paper no. 02-21, November.

Lee, Donghoon, and Wilbert van der Klaauw. 2010. "An Introduction to the FRBNY Consumer Credit Panel." Federal Reserve Bank of New York Staff Reports, no. 479, November.

Morgan, Donald, Benjamin Iverson, and Matthew Botsch. 2008. "Seismic Effects of the Bankruptcy Reform.” Federal Reserve Bank of New York Staff Reports, no. 358, November.

Sullivan, James X. 2008. "Borrowing during Unemployment: Unsecured Debt as a Safety Net." Journal of Human Resources 43 no. 2 (spring): 383-412.

Whitehouse, Mark. 2010. "Defaults Account for Most of Pared Down Debt," Wall Street Journal Real Time Economics Blog, September 18. http://blogs.wsj.com/ economics/2010/09/18/number-of-the-week-defaults-account-for-most-of -pared-down-debt/; last accessed October 1, 2010.

Zinman, Jonathan. 2009. "Where Is the Missing Credit Card Debt? Clues and Implications." Review of Income and Wealth 55, no. 2 (June): 249-65.

\footnotetext{
${ }^{13}$ See http://www.newyorkfed.org/research/national_economy/ nationalindicators.html ("Household Credit Conditions") for quarterly releases of many of the key data series and occasional supplemental reports.
}

\section{ABOUT THE AUTHORS}

Meta Brown and Donghoon Lee are senior economists, Andrew Haughwout a vice president, and Wilbert van der Klaauw a senior vice president in the Microeconomic Studies Function of the Federal Reserve Bank of New York.

Current Issues in Economics and Finance is published by the Research and Statistics Group of the Federal Reserve Bank of New York. Linda Goldberg and Thomas Klitgaard are the editors of the series.

Editorial Staff: Valerie LaPorte, Mike De Mott, Michelle Bailer, Karen Carter, Anna Snider

Production: Jane Urry, Jessica lannuzzi, David Rosenberg

Back issues of Current Issues are available at http://www.newyorkfed.org/research/current_issues/.

The views expressed in this article are those of the authors and do not necessarily reflect the position of the Federal Reserve Bank of New York or the Federal Reserve System. 


\section{RELATED READINGS FROM THE FEDERAL RESERVE BANK OF NEW YORK}

\section{Publications of the Research and Statistics Group} Available at http://www.newyorkfed.org/research/publication _annuals/index.html

\section{An Introduction to the FRBNY Consumer Credit Panel}

Donghoon Lee and Wilbert van der Klaauw

Staff Reports, no. 479, November 2010

In this paper, the authors introduce the FRBNY Consumer Credit Panel, a new longitudinal database with detailed information on consumer debt and credit. The panel uses a unique sample design and information derived from consumer credit reports to track individuals' and households' access to and use of credit at a quarterly frequency. In any given quarter ranging from the first quarter of 1999 to the present, the panel can be used to compute nationally representative estimates of the levels and changes in various aspects of individual and household liabilities. In addition to describing the sample design, the use of sample weights, and the credit report information included in the database, the authors provide some comparisons of population statistics and consumer debt estimates derived from the panel with those based on data from the American Community Survey and the Flow of Funds Accounts of the United States.

Household Debt and Credit Report

Available at http://www.newyorkfed.org/householdcredit/

The Federal Reserve Bank of New York's Household Debt and Credit Report provides a quarterly snapshot of household trends in borrowing and indebtedness, including data about mortgages, student loans, credit cards, auto loans, and delinquencies. The report aims to help community groups, small businesses, state and local governments, and the public to better understand, monitor, and respond to trends in borrowing and indebtedness at the household level.

\section{The Liberty Street Economics Blog}

Available at http://libertystreeteconomics.newyorkfed.org/

Just Released: Press Briefing on Household Debt and Credit Meta Brown, Andrew Haughwout, Donghoon Lee, Joelle Scally, and Wilbert van der Klaauw

Liberty Street Economics blog, February 28, 2013

The results of the New York Fed's latest Quarterly Report on Household Debt and Credit - with special emphasis on household borrowing and student loans-are presented.
Just Released: Has Household Deleveraging Continued?

Andrew Haughwout, Donghoon Lee, Joelle Scally, and Wilbert van der Klaauw

Liberty Street Economics blog, August 29, 2012

The bloggers use newly available 2010 and 2011 FRBNY Consumer Credit Panel data to update their analysis on household deleveraging (presented in a March 21,2011, Liberty Street Economics blog post).

\section{Grading Student Loans}

Meta Brown, Andrew Haughwout, Donghoon Lee, Maricar Mabutas, and Wilbert van der Klaauw

Liberty Street Economics blog, March 5, 2012

Brown, Haughwout, Lee, Mabutas, and van der Klaauw examine the overall student loan debt market as of third-quarter 2011, and find it likely that delinquency rates for these loans are understated.

"Flip This House": Investor Speculation and the Housing Bubble

Andrew Haughwout, Donghoon Lee, Joseph Tracy, and Wilbert van der Klaauw

Liberty Street Economics blog, December 5, 2011

During 2004-06, real estate "investors" used financial leverage (mortgage credit) to purchase multiple residential properties, which likely helped push house prices up. But when prices turned down in early 2006, these investors defaulted in large numbers and contributed to the intensity of the housing bust.

\section{Have Consumers Been Deleveraging?}

Meta Brown, Andrew Haughwout, Donghoon Lee, and Wilbert van der Klaauw

Liberty Street Economics blog, March 21, 2011

Since its peak in summer 2008, U.S. consumers' indebtedness has fallen by more than a trillion dollars. The bloggers demonstrate that a significant part of the debt reduction was produced by consumers borrowing less and paying off debt more quickly-a process often called deleveraging. 